\title{
Influence of the Use of Selected and Non-selected Yeasts in Red Wine Production
}

\author{
Daniela Dorneles, Iara Maria Pereira Machado, Miriam Blumel Chociai and Tania Maria \\ Bordin Bonfim* \\ Laboratório de Enzimologia e Tecnologia das Fermentações; Departamento de Farmácia; Universidade Federal do \\ Paraná; Rua Lothário Meissner, 3400; tbonfim@ufpr.br; 80210-170; Curitiba - PR - Brasil
}

\begin{abstract}
The aim of this work was to study the influence of use of Saccharomyces cerevisiae selected varieties in the elaboration of Terci red wine from Colombo. The winemaking method followed the classic red wine vinification system and the samples were analyzed according to the official table wine methods. The assays performed showed differences mainly over volatile acids, acetaldehyde, esters and methanol contents, confirming that the use of selected yeasts contributed on improving the wine quality.
\end{abstract}

Key words: Fermentation; red wine; selected yeasts

\section{INTRODUCTION}

The key role of yeasts in conducting the alcoholic fermentation, the most important chemical reaction in winemaking, has been recognized. In spontaneous fermentation, the transformation of grape must into wine is carried out by yeast biota naturally present in the must. Several factors affect the resident yeast biota with the subsequent wine quality variations from one year to another (Sanni and Lönner, 1993; Lopes et al., 2002). Many of the indigenous non-Saccharomyces yeast genera present in the must are capable of producing relatively large amounts of undesirable and inhibitory metabolites, such as acetic acid and acetaldehyde (Schütz and Gafner, 1993; HenickKling et al., 1998) and can be responsible for differences in the sensorial and physical-chemical parameters of the wine, interfering in its quality and its safe use (Egli et al., 1998; Pretorius, 2001).
Despite of the technological development of the wine industry in Brazil, since 1970, the use of indigenous yeasts in the fermentation process is still a practice of little wineries, which keep old family traditions on the wine production (Costa, 1993). Currently, about 6,300 ha are grown and more than 90,000 $\mathrm{t}$ of grape are produced per year in Paraná State, according to the official data. About 800,000 liters of wine/year are produced by spontaneous fermentation only in Colombo County (Paraná), which is a very significant amount, comparing to the production of others regions of Paraná State, that do not use an artisanal method.

Inoculation with a starter culture is intended to establish a high population of a selected strain of Saccharomyces cerevisiae from the beginning of fermentation to ensure its dominance. It results in a rapid production of alcohol and consequent minimization of the growth of non-Saccharomyces yeasts present. Moreover, it reduces the

\footnotetext{
${ }^{*}$ Author for correspondence
} 
fermentation time and allows the formation of wines with a predictable flavor (Henick-Kling et al., 1998; Zoecklein et al., 2001; Comi and Croattini, 1997). In order to improve the quality parameters and ensure a better standardization of the wine characteristics, the aim of this work was to produce wines using selected yeasts and compare their characteristics to the wine produced in Colombo (Paraná, Brazil) by indigenous yeasts, using the same harvest grape.

\section{MATERIALS AND METHODS}

\section{Grape}

The must used was Vitis labrusca, Terci cultivar. A sample of $97 \mathrm{~kg}$ of grape was harvested in January 2002 in a winery in Colombo (Paraná, Brazil).

\section{Selected yeasts strains}

Three active dry enological yeasts were selected and individually used in the fermentation of the must: Uvaferm BC (Saccharomyces cerevisiae var. bayanus); Uvaferm CK (Saccharomyces cerevisiae var. cerevisiae); Uvaferm BDX (Saccharomyces cerevisiae var. cerevisiae). All of them were obtained from Danster Ferment AG.

\section{Must preparation}

After the washing for the removal of the copper residue provided by the antiseptic treatment, the grapes were destemmed and crushed for the release of the pulp and the juice. The determination of the soluble solids, reducing and non-reducing sugars, total acidity and nitrogen content was done in the juice. Based on these determinations, the suitable correction in the sugar and nitrogen content was done in order to obtain a wine above $20 \mathrm{~g}$ glucose/L, with the desired alcoholic content (between 10 and $13{ }^{\circ} \mathrm{GL}$ ) and nutritional development of the yeast (final content of $300 \mathrm{mg} \mathrm{N} / \mathrm{L}$ ), respectively. Potassium metabisulfite was added at the concentration of $75 \mathrm{mg} \mathrm{SO} / \mathrm{L}$, in order to reduce the population of undesirable microorganisms during the fermentation (Chociai et al., 2000). The three strains were re-hydrated and added to the must after $6 \mathrm{~h}$ of the sulfite addition, following the concentration suggested by the yeast supplier $(20 \mathrm{~g} / \mathrm{hL})$.

\section{Fermentation procedures}

The wines were obtained by classical vinification method as described by Meneguzzo (1990). After 5 days of the fermentation, the peels were taken from the must (partially fermented). A new correction on the sugar content was done because only half of the planned sucrose amount was added in the beginning of the fermentation. In the second phase the natural process of clarification began. A hydraulic plug was adapted to the vats in order to avoid the entrance of air and the possible oxidation of the beverage. After 37 days, the wine was separated from the residues originated from the fermentation. This process was repeated after 105 days to ensure a perfect stabilization and clarification of the wine before the process of bottling (Chociai et al, 2000).

\section{Physical-chemical analyses of the wine}

The determinations, of alcoholic grade, total sugars, volatile and total acidity, methanol, $\mathrm{pH}$, ethyl acetate, acetaldehyde, total sulfur dioxide and ashes were done by official methods (Ministério da Agricultura, 1986). The determination of copper and iron was analyzed by the procedures described by AOAC (2000). The nitrogen determination was done by the method described by Walter (1953). All the analysis was made with triplicate samples.

\section{RESULTS AND DISCUSSION}

The grape juice obtained in laboratory scale showed a soluble solids content of $14.5{ }^{\circ}$ Brix, confirmed by the determination of reducing and non-reducing sugars. Based on the determinations showed on Table $1,14^{\circ}$ Brix of sucrose and 216 $\mathrm{mg}$ nitrogen/L (diammonium phosphate form), were added to start the fermentation of selected yeast wine. Total solid content under the usual (15 - $19{ }^{\circ}$ Brix) and high total acidity could be justified by the weather and soil conditions of the place, that are not always ideal every harvest (Miele et al, 1994).

The amount of sulfite added contributed to the predominance of the selected yeasts added to the must, as observed by other authors (Henick-Kling et al., 1988; Ciani and Pepe, 2002; Lopes et al., 2002). The inoculation of the yeasts was extremely facilitated, being directly added to the must without previously pre-multiplication (Comi and Croattini, 1997). 
Table 1 - Analysis of the Terci grape juice

\begin{tabular}{l|c}
\multicolumn{1}{c|}{ Analysis } & Results \\
\hline Soluble solids & $14.5^{\circ} \mathrm{Brix}$ \\
Total acidity & $128.63 \mathrm{meq} / \mathrm{l}$ \\
Nitrogen content & $84 \mathrm{mg} / \mathrm{l}$ \\
Reducing sugars & $142.80 \mathrm{~g} / \mathrm{l}$ \\
Non-reducing sugars & $1.728 \mathrm{~g} / \mathrm{l}$ \\
\hline
\end{tabular}

After the beginning of selected yeast fermentation, transformation of great part of the fermentable sugars to ethyl alcohol and $\mathrm{CO}_{2}$ was observed. Comparing the analysis of the wines produced to the reference wine obtained from a Colombo winemaker (Table 2), it was found that the three samples tested showed an average alcoholic grade around $13.46{ }^{\circ} \mathrm{GL}$, while the reference wine showed an alcoholic grade around $15.43{ }^{\circ} \mathrm{GL}$, above the value allowed by the Brazilian official parameters $\left(10\right.$ to $\left.13{ }^{\circ} \mathrm{GL}\right)$. The average total sugar concentration obtained was $40 \mathrm{~g} / \mathrm{L}$ on the selected yeast wines produced and $103.20 \mathrm{~g} / \mathrm{L}$ on the reference one, obtained by indigenous strains. The high alcoholic grade and the excess of sugar found in the artisanal wine could be explained by the technical difficulty in the standardization of the must before the beginning of fermentation, but otherwise expressed the high alcohol level tolerance and productive capacity.

It was also observed that the total acidity was above the limits specified by the Brazilian official parameters, suggesting desacidification process to correct this value. The volatile acidity, characterized by the presence of acetic acid, was higher in the reference wine, because of the presence of indigenous microorganisms, especially Acetobacter (Costa, 1993; Zoecklein et al., 2001). The $\mathrm{pH}$ value agreed with the $\mathrm{pH}$ proposed by Amerine and Ough (1976) and Copat (1988), which were below 3.6 and between 3.0 and 3.2.

Methanol, produced by the enzymatic hydrolysis of the pectin present in the grape, varied between 120 to $250 \mathrm{mg} / \mathrm{L}$ in red wines (Zoecklein et al., 2001). The legislation allows contents below 350 $\mathrm{mg} / \mathrm{L}$. All the samples were below this limit, but the reference wine showed the highest content.

Artisanal wine presented ethyl acetate content above the content presented by the selected yeast wines. The same was found by Fraile et al. (2000). Ethyl acetate contributes with the acetic acid to the characteristic aroma of vinegar found in the wines. Acetaldehyde is a normal product of the alcoholic fermentation, but concentrations above $100 \mathrm{mg} / \mathrm{L}$ are related to oxidative processes.

Table 2 - Analysis of the wines obtained from selected and non-selected yeasts

\begin{tabular}{l|r|r|r|r|r}
\hline \multicolumn{1}{c}{ Analysis } & \multicolumn{1}{c}{ BC } & \multicolumn{1}{c}{ BDX } & CK & Colombo & $\begin{array}{c}\text { Official } \\
\text { Parameters }\end{array}$ \\
\hline Alcoholic grade $\left({ }^{\circ} \mathrm{GL}\right)$ & $13.31 \pm 0.19$ & $13.49 \pm 0.10$ & $13.59 \pm 0.21$ & $15.43 \pm 0.21$ & $10 \mathrm{a} 13$ \\
Total sugars (g/L) & $43.42 \pm 1.56$ & $36.92 \pm 1.86$ & $36.42 \pm 0.92$ & $103.20 \pm 2.17$ & $>20$ \\
Total acidity (mEq/L) & $126.84 \pm 1.39$ & $143.15 \pm 0.72$ & $140.13 \pm 2.46$ & $102.60 \pm 0.78$ & 55 a 130 \\
Volatile acidity (mEq/L) & $2.73 \pm 0.27$ & $2.72 \pm 0.63$ & $6.13 \pm 0.07$ & $11.22 \pm 0.06$ & $<20$ \\
PH & $3.08 \pm 0.01$ & $3.05 \pm 0.02$ & $3.09 \pm 0.03$ & $3.14 \pm 0.02$ & - \\
Methanol (mg/L) & $200.37 \pm 0.00$ & $162.76 \pm 2.31$ & $216.33 \pm 3.89$ & $260.48 \pm 0.00$ & $<350$ \\
Ethyl acetate (mg/L) & $103.37 \pm 0.00$ & $131.96 \pm 9.33$ & $169.35 \pm 0.00$ & $327.70 \pm 0.00$ & - \\
Acetaldehyde (mg/L) & $38.15 \pm 1.63$ & $58.96 \pm 1.63$ & $36.99 \pm 0.00$ & $106.36 \pm 0.00$ & - \\
Total sulfur dioxide (mg/L) & $9.27 \pm 0.92$ & $9.27 \pm 4.86$ & $6.09 \pm 2.43$ & $16.69 \pm 0.00$ & $<350$ \\
Nitrogen (mg/L) & $13.67 \pm 0.00$ & $20.50 \pm 0.00$ & $25.06 \pm 3.95$ & $37.59 \pm 4.83$ & - \\
Ash (g/L) & $2.00 \pm 0,00$ & $2.05 \pm 0.212$ & $2.30 \pm 0.14$ & $1.60 \pm 0,14$ & $>1.5$ \\
Copper (mg/L) & 0.08 & 0.13 & 0.07 & $<0.01$ & - \\
Iron (mg/L) & 0.25 & 0.19 & 0.28 & 0.32 & - \\
\hline
\end{tabular}


The highest acetaldehyde and ethyl acetate levels could be related to the use of non-selected yeasts and higher aeration of the wine (Romano et al., 1994). The strain BC produced lower amounts of acetaldehyde, as specified by the supplier.

The sulfite concentration of $75 \mathrm{mg} / \mathrm{L}$ added to the grape juice at the beginning of the laboratory scales fermentation was consumed (about $89.05 \%$ ). A certain amount of $\mathrm{SO}_{2}$ added to the preliminary phases is lost during the fermentation (Benassi, 1997). Miele et al. (1994) suggested that $35 \mathrm{mg}$ total sulfur dioxide/L was a very low concentration, despite the worldwide tendency in reducing its concentration on wine production because of public health reasons, the good quality of the fruit and the desire of carrying out the malolactic fermentation.

As regards the ash content, all the samples were in accordance with the official Brazilian parameters (higher than $1.5 \mathrm{~g} / \mathrm{L}$ ). It was observed that the reference wine showed a value very close to the limit that could be justified by the amount of sugar added to the finished product (Amerine and Ough, 1976). The copper contents were considered normal to Brazilian red wines (Miele et al., 1994). As regards to the iron content, all the samples showed values below those usually found (1 to 5 $\mathrm{mg} / \mathrm{L}$ ) (Miele et al., 1994). It could be explained by the non-utilization of iron-made equipments during the producing of the artisanal and laboratorial wines.

\section{CONCLUSION}

It was found that the production of red wines using selected yeasts under the conditions tested contributed in improving the physical-chemical parameters of the wines obtained, reducing some undesirable components in the finished product, like the volatile acidity, ethyl acetate, methanol and acetaldehyde, when compared to the artisanal wine. The addition of the yeasts promoted a decrease in the fermentation time, a good alcoholic yield, demonstrating their dominance in the must, tolerate the sulfite added and the high alcoholic grade. Their use also promoted a more homogeneous fermentation. Future work includes to isolate yeast found in the Vitis labrusca variety used at Colombo county and determinate some properties, as their fermentative capacity and alcohol tolerance. Evaluation of volatile acidity and ethyl acetate using another methodologies is also left as future work, since the volatile acidity levels do not correspond to the ethyl acetate levels found in the samples tested.

\section{RESUMO}

Dentre os diferentes tipos de vinho, o vinho proveniente de Vitis labrusca ainda é o mais consumido no Brasil. Seu preparo em pequenas vinícolas envolve antigas tradições que acarretam características indesejáveis e imprevisíveis à bebida. Em Colombo (Paraná, Brasil) são cultivados anualmente 130 hectares de videiras, produzindo 1300 toneladas de uvas comuns do gênero Vitis labrusca e 800.000 L/ano de vinho artesanal de mesa, sem nenhum procedimento padronizado, como o uso de leveduras selvagens. O objetivo deste trabalho foi estudar a influência do uso de variedades selecionadas de Saccharomyces cerevisiae na elaboração de vinho tinto com uva Terci, proveniente do município de Colombo. A técnica de preparo dos vinhos seguiu o sistema clássico de vinificação para vinhos tintos e as amostras foram analisadas de acordo com os métodos oficiais. Os resultados demonstraram diferenças nas amostras, principalmente em relação aos teores de acidez volátil, acetaldeído, ésteres e metanol, comprovando que com a utilização de leveduras selecionadas contribui para melhorar os parâmetros de qualidade e padronização do vinho.

\section{REFERENCES}

Amerine, M. A. and Ough, C. S. (1976), Analisis de vinos y mostos. Zaragoza: Acribia.

Association of Official Analytical Chemists (2000), Metals and other elements. In: Official Methods of Analysis of AOAC International. Gaithersburg. pp. 15-20.

Benassi, M. T. (1997), Metodologia analítica para avaliação de parâmetros físico-químicos e sensoriais de qualidade em vinhos Riesling Itálico nacionais. $\mathrm{PhD}$ Thesis, Universidade Estadual de Campinas, Campinas, Brazil.

Chociai, M. B.; Bonfim, T. M. B. Chociai, J. G. and Fonseca, P. (2000), Elaboração de vinhos. Imprensa Universitária da Universidade Federal do Paraná, Curitiba. 
Ciani, M. and Pepe, V. (2002), The influence of prefermentative practices on the dominance of inoculated yeast starter under industrial conditions. $J$. Sci. Food Agric., 82, 573-578.

Comi, G. and Croattini, I. (1997), The oenological characteristics of commercial dry yeasts. J. Wine Res., 8 : (2), 81-86.

Copat, L. (1988), A produção de uvas no Brasil e a problemática do vinho comum. Revista do Vinho, 2 : (19), 27-33.

Costa, R. M. (1993), Elaboração e controle de qualidade de vinho tinto suave de mesa da região de Santa Felicidade. Msc Thesis, Universidade Federal do Paraná, Curitiba, Brazil.

Egli, C. M.; Edinger, W. D.; Mitrakul, C. M. and Henick-Kling, T. (1998), Dynamics of indigenous and inoculated yeast populations and their effect on the sensory character of Riesling and Chardonnay wines. Journal of Applied Microbiology, 85, 779-789.

Fraile, P.; Garrido, J. and Ancín, C. (2000), Influence of a Saccharomyces cerevisiae selected strain in the volatile composition of rosé wines: evolution during fementation. J. Agric. Chem., 48, 1789-1798.

Henick-Kling, T.; Edinger, W.; Daniel, P. and Monk, P. (1998), Selective effects of sulfur dioxide and yeast starter culture addition on indigenous yeast populations and sensory characteristics of wine. $J$. Appl. Microbiol., 84, 865-876.

Lopes, C. A.; Van Broock, M.; Querol, A. and Caballero, A. C. (2002), Saccharomyces cerevisiae wine yeast populations in a cold region in Argentinean Patagonia: a study at different fermentation scales. J. Appl. Microbiol., 93, 608-615.

Meneguzzo, J. (1990), Sistemas de vinificação para vinhos tintos: sistema clássico. Revista do Vinho, 4 : (19), 28-29.

Miele, A.; Rizzon, L. A. and Zanuz, M. C. (1994), Avaliação nacional de vinhos: safra 1993. Bol. SBCTA, 28 : (2), 161-169.

Ministério da Agricultura (1986), Portaria 076 que estabelece métodos oficiais de análises para destilados alcoólicos, destilados retificados e alcoólicos por mistura. Diário Oficial da União, Brasília.

Pretorius, I. S. (2001), Gene technology in winemaking: new approaches to an ancient art. Agriculturae Conspectus Scientificus, 66 : (1), 27-47.

Romano, P.; Suzzi, G.; Turbanti, L. and Polsinelli, M. (1994), Acetaldehyde production in Saccharomyces cerevisiae wine yeasts. FEMS Microbiology Letters, 118, 213-218.
Sanni, A. I. and Lonner, C. (1993), Identification of yeasts isolated from Nigerian traditional alcoholic beverages. Food Microbiology, 10, 517-523.

Schutz, M. and Gafner, J. (1993), Analysis of yeast diversity during spontaneous and induced alcoholic fermentations. Journal of Applied Bacteriology, 75, 551-558.

Walter, F. G. (1953), The manufacture of compressed yeast. London: Chapman and Hall.

Zoecklein, B. W.; Fugelsang, K. C.; Gump, B. H. and Nury, F. S. (2001), Análisis y producción de Vino. Zaragoza: Acribia.
Received: February 06, 2004; Revised: November 18, 2004; Accepted: August 09, 2005. 